\title{
Expression, Secretion, and Age-Related Downregulation of Pigment Epithelium-Derived Factor, a Serpin with Neurotrophic Activity
}

\author{
Joyce Tombran-Tink, ${ }^{1}$ Sunil M. Shivaram, ${ }^{1,2}$ Gerald J. Chader, ${ }^{1}$ Lincoln V. Johnson, ${ }^{3}$ and Dean Bok ${ }^{4}$ \\ 'Laboratory of Retinal Cell and Molecular Biology, National Eye Institute, National Institutes of Health, Bethesda, \\ Maryland 20892, ${ }^{2}$ Howard Hughes Medical Institute, Bethesda, Maryland 20814, ${ }^{3}$ Department of Cell and

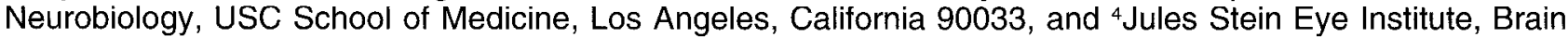 \\ Research Institute and Department of Anatomy and Cell Biology, UCLA School of Medicine, Los Angeles, California \\ 90024
}

Retinal pigment epithelial (RPE) cells form a functional complex with photoreceptor neurons of the retina, interacting through the interphotoreceptor matrix (IPM). We now provide evidence that the gene for pigment epithelium-derived factor (PEDF), a protein possessing neurotrophic and neuronal-survival activities, is highly expressed by both fetal and young adult RPE cells. PEDF mRNA is present in RPE cells of the human eye at 17 weeks of gestation, demonstrating its potential for action in vivo during early retinal development. The PEDF protein is secreted in vivo where it constitutes a part of the fetal and adult IPM surrounding photoreceptor outer segments. A polyclonal PEDF antibody recognizes at least four isoforms of secreted human and bovine PEDF by two dimensional gel analysis, and detects a similar $50 \mathrm{kDa}$ protein in the IPM of several other vertebrate species. Within soluble extracts of RPE cells, however, where little, if any, of the $50 \mathrm{kDa}$ species can be detected, an immunoreactive $36 \mathrm{kDa}$ protein is observed by Western blot analysis. By Immunofluorescence, PEDF is localized intracellularly in association with the nucleus, presumptive secretory granules, and cytoskeletal elements of cultured RPE cells with PEDF and actin antibodies colocalizing to the same cytoskeletal structures. During initial stages of attachment, PEDF and actin also concentrate at the tips of pseudopods extended by the cultured RPE cells. However, with successive passages, synthesis, and secretion of the PEDF protein as well as transcription of its mRNA decrease and are lost by about 10 passages. In parallel, cultured RPE cells lose their proliferative potential and change from an epithelial-like morphology in early passages to a more fibroblast-like appearance by about the 10th passage. PEDF is thus apparently present intracellularly and extracellularly in both fetal and early adult periods where it could be involved in cellular differentiation and survival and with its loss, in the onset of senescence.

[Key words: serpin, neurotrophic factor, pigment epithe-

\footnotetext{
Received Sept. 14, 1994; revised Feb. 9, 1995; accepted Feb. 16, 1995.

We thank Marcia Lloyd, Orna Yaron, and Alice Van Dyke for expert technical assistance with the in situ hybridizations. L.V.J. was supported by NEI EY04741. D.B. was supported by NEI EY00444, NEI EY00331, the National RP Foundation Fighting Blindness, and the Dully Green Enduwment.

Correspondence should be addressed to Dr. Joyce Tombran-Tink, Building 6, Room 311, National Eye Institute, National Institutes of Health, Bethesda, MD 20892.

Copyright (C) 1995 Society for Neuroscience $\quad 0270-6474 / 95 / 154992-12 \$ 05.00 / 0$
}

lium-derived factor (PEDF), aging, cytoskeletal structure, neural retina, pigment epithelium, interphotoreceptor matrix, actin, tissue culture]

The retinal pigment epithelium (RPE) is a highly specialized neuroepithelium of the eye that plays a critical role in retinal homeostasis. Functionally, RPE cells have been compared to macrophages (Young and Bok, 1969; Elner et al., 1981), oligodendrocytes (Steinberg and Wood, 1974), astrocytes (Immel and Steinberg, 1986; Fox et al., 1988), melanocytes (FeeneyBurns, 1980) and hepatocytes (Bok, 1985). Its strategic positioning between the choriocapillaris (basally) and the retinal photoreceptor cells (apically) and the presence of tight junctional complexes allows the RPE to serve as a major part of the bloodretinal barrier (Cunha-Vaz, 1979) and to function as a transporting and absorbing epithelium, controlling the milieu of the photoreceptor elements (Miller and Steinberg, 1982). Any disruption therefore of its relationship with the neural retina could cause photoreceptor cell pathology and thus adversely affect the visual process (Hollyfield and Witkovsky, 1974). Evidence of its potential to secrete growth/trophic factors, for example, bFGF (Schweigerer et al., 1987), PDGF (Campochiaro et al., 1989), and IGF (Waldbillig et al., 1991), makes the role of the RPE in relation to the developing retina of even greater interest. These products are contained in the retinal interphotoreceptor matrix (IPM), an extracellular domain between the RPE cells and the adjacent retinal photoreceptor outer segments (Hageman and Johnson, 1991).

A unique $50 \mathrm{kDa}$ protein, pigment epithelium-derived factor (PEDF), that is secreted by human fetal RPE cells in culture has been identified and shown to induce neuronal differentiation of human Y-79 retinoblastoma cells in vitro (Tombran-Tink and Johnson, 1989; Tombran-Tink et al., 1991; Steele et al., 1993). When treated with purified PEDF (Tombran-Tink et al., 1991; Stecle ct al., 1993) or with crude soluble IPM cxtracts containing PEDF (Tombran-Tink et al., 1992), the Y-79 cells elaborate an abundance of neurite-like outgrowths and upregulate known neuronal marker molecules. Functionally, PEDF also maintains the long-term survival of the neuronally differentiated Y-79 cells (Tombran-Tink and Johnson, 1989) and acts as a neuronal-survival factor for cerebellar granule cells in culture (Taniwaki et al., 1994). Relative to this, PEDF has previously been shown to be expressed by cultured WI-38 lung fibroblast cells where its downregulation is linked to the process of senescence (Pignolo et al., 1993). The PEDF gene has been cloned and sequenced 
and shown to be a member of the serine protease inhibitor (serpin) gene family (Steele et al., 1993). Sequence homology at the known serpin reactive site is low, however, and thus PEDF's biological effects may not involve classical antiprotease action (Steele et al., 1993; Becerra et al., 1994). The gene is conserved in higher vertebrates and can be detected in almost all human cell types (Tombran-Tink et al., in preparation). The gene is also of interest since it maps to human chromosome $17 \mathrm{p} 13.1$, a region containing a cluster of cancer-related genes (Tombran-Tink et al., 1994).

To date, however, little information has been obtained as to the important questions of synthesis and secretion of PEDF. In this study, we present evidence for the expression of PEDF by fetal and adult RPE cells as well as its secretion into both fetal and adult IPM in vivo. Moreover, we have used a well-defined RPE cell culture system to demonstrate (1) the intracellular localization of PEDF, (2) the presence of a unique intracellular 36 $\mathrm{kDa}$ PEDF spccics, and (3) the apparent downregulation of PEDF expression with cellular aging.

\section{Materials and Methods}

RPE cells and conditioned medium (CM). Monkey eyes were obtained through the courtesy of the Office of Biologics, FDA. The procedures for establishing RPE cells in culture and describing their differentiated characteristics have been published previously (Pfeffer, 1990). In the present study, conditioned medium and cultured monkey RPE cells were used from the first, second, fifth, 10th, and 15th passages. The cells were routinely seeded at approximately $10^{3}$ cells, maintained in Minimal Essential Medium (MEM, Eagle's salts, Mediatech, Hearndon, VA) containing $0.5 \%$ fetal calf serum (FCS, GIBCO, Grand Island, NY), and passaged at confluency. Cell growth was estimated from the time need ed to reach confluency after seeding $10^{3}$ cells in a $150 \mathrm{~cm}^{2}$ flask (Corning, Corning, NY). When appropriate, growth rates were also estimated after a scrum challenge of $10 \%$ ГCS.

Cells from confluent monolayer cultures were either used for immunocytochemistry or scraped from flasks, solubilized in phosphatebuffered saline (PBS, pH, 7.4) containing $0.5 \%$ Triton X-100 (Sigma Chemical Co., St. Louis, MO), and stored at $-70^{\circ} \mathrm{C}$ for Western blot analysis. For Northern blot analysis, the following sources of RNA were used: (1) cultured fetal and adult human RPE cells (Flannery et al., 1990); (2) human RPE cell explants from 21 week gestational donors (obtained from Dr. W. O'Day, Jules Stein Eye institute, UCLA); (3) human and monkey retina (Clonetech, Palo Alto, CA); (4) cultured monkey RPE cells at different passages (eyes obtained through the courtesy of the In Vitro Vaccine Testing Section, FDA, Bethesda, MD).

Conditioned medium (CM) from cultured fetal and adult human RPE cells was obtained from monolayer cell cultures grown as previously described (Carlson and Bok, 1992). CM from primary cultures of RPE cells from young adult monkey and from 11-d-old chick embryos were generous gifts of Dr. Bruce Pfeffer (NEI) and Dr. Margaret Koh (Univ. of Maryland Med. School), respectively. The medium was conditioned for $7 \mathrm{~d}$ by confluent monolayers of the RPE cells, filter sterilized, and stored at $-70^{\circ} \mathrm{C}$ until use. Media conditioned by confluent monolayers of monkey RPE cells in their first, second, fifth, 10th, and 15th passages were used for Western blot analysis to study the secretion of PEDF with successive cell passages.

Isolation of IPM, retinal, and RPE cells. Soluble IPM preparations were obtained from adult human (obtained from the Clinical Branch, NEI), fetal bovine (10 weeks gestation), and adult bovine eyes (obtained from Trueth and Sons, Baltimore, MD), as previously described (Tombran-Tink et al., 1992). Briefly, the anterior segment, lens, and vitreous were removed. The neural retina was removed from the underlying RPE cell layer and the resultant eye cups and retinas were gently rinsed with $0.5 \mathrm{ml}$ of PBS solution. This preparation, containing mostly readily soluble IPM components, was centrifuged and the supernatant stored at $-70^{\circ} \mathrm{C}$. RPE cells were removed from the eye cup by vigorous, repeated pipetting of a small amount of PBS against the cells in situ to detach them from the underlying Bruch's membrane. The retina and the RPE cells were subsequently solubilized in SDS sample buffer to be used for Western blot analysis.

SDS-PAGE analyses. Protein concentrations were determined using the BCA assay (Pierce Chem. Co., Rockford, IL) according to the manufacturer's specifications. Samples of conditioned medium, IPM or cell extracts, were lyophilized and $15 \mu l$ of each reconstituted in SDS sample buffer and boiled for $5 \mathrm{~min}$. The proteins were fractionated on $10 \%$ polyacrylamide gels at $25 \mathrm{~mA} / \mathrm{gel}$ constant current for $3 \mathrm{hr}$ (Laemmli, 1970 ). Five microgram samples of human $\alpha$-1-antitrypsin and $\beta$-actin (Sigma Chemical Co.) were included on the gels as controls. The resultant gels were either stained with Coomassie brilliant blue (Sigma) for visualization of the electrophoretic protein profile or transblotted onto nitrocellulose membranes for Western blot analysis.

Two dimensional gel analysis of (1) purified PEDF protein from CM of cultured fetal RPE cells (Tombran-Tink et al., 1991), (2) CM from cultured human RPE cells (Tombran-Tink et al., 1991), and (3) adult bovine IPM (Tombran-Tink et al., 1992) was performed according to the method of O'Farrell (1975). Isoelectric focusing was carried out in glass tubes of inner diameter $2.0 \mathrm{~mm}$, using $2 \% \mathrm{BDH} \mathrm{pH} 48$ ampholines for $9600 \mathrm{~V}$ hr. The final tube gel $\mathrm{pH}$ gradient extended from about $\mathrm{pH} 4.0$ to about $\mathrm{pH} 8.2$, as measured by a surface $\mathrm{pH}$ electrode. After equilibration for 10 min in bufler O $(10 \%$ glycerol, $50 \mathrm{~mm}$ dithiothreitol, 2.3\% SDS and $62.5 \mathrm{~mm}$ Tris, $\mathrm{pH} 6.8$ ), the tube gel was sealed to the top of a $10 \%$ acrylamide slab gel $(0.75 \mathrm{~mm}$ thick $)$ and electrophoresis was carried out for $4 \mathrm{hr}$ at $12.5 \mathrm{~mA} / \mathrm{gel}$. The gels were then either stained with Coomassie blue or transblotted onto nitrocellulose membranes for Western blot analysis.

Western blot analysis. Nitrocellulose membranes containing the transblotted proteins were pretreated with $0.5 \%$ nonfat dried milk in 50 $\mathrm{mm}$ Tris buffer ( $\mathrm{pH}$ 7.4) followed by incubation for $1 \mathrm{hr}$ with a polyclonal antibody prepared against human PEDF (a generous gift of Dr. Vincent Cristofalo, Medical College of Pennslyvania) diluted at 1:3000 in Tris buffer containing $0.5 \%$ milk. After this treatment, the membranes were washed extensively with Tris buffer and subjected to further incubation for $30 \mathrm{~min}$ in an appropriate dilution of alkaline phosphataseconjugated goat anti-rabbit IgG. The alkaline phosphatase color development reagents p-nitro blue tetrazolium chloride (NBT) and 5-bromo4-chloro-3'-indoyl phosphate p-toluidine salt (BCIP) (Bio Rad Lab, Richmond, CA) were used for the detection of the PEDF protein.

Polymerase chain reaction $(P C R)$. First strand cDNA synthesis of human, monkey, and bovine RPE cell mRNA was performed using the SuperScript Preamplification System catalyzed by SuperScript RNase H-Reverse Transcriptase (RT) (GIBCO, Bethesda Research Labs, Gaithersburg, MD). Three microliters of the resulting first strand cDNA was then used for each PCR reaction. A pair of primers from the translated sequences of the human PEDF cDNA (Steele et al., 1993), representing a 1472 base pair (bp) PCR amplification product, was used in the reactions. The primers are as follows: (1) primer 601, $5^{\prime}$-GGA CGC TGG ATT AGA AGG CAG- $3^{\prime}$; and (2) primer $499,5^{\prime}$-TTG TAT GCA TTG AAA CCT TAC AGG-3'. The PCR reaction contained $10 \mathrm{~mm}$ Tris- $\mathrm{HCl}$ $(\mathrm{pH} 8.3), 50 \mathrm{mM} \mathrm{KCl}, 80 \mu \mathrm{M}$ of each dNTP, $1 \mathrm{mM} \mathrm{MgCl}, 100 \mathrm{ng}$ of each primer, and $1.25 \mathrm{U}$ of Amplitaq (Perkin Elmer Cetus). A preamplification denaturation for $10 \mathrm{~min}$ at $94^{\circ} \mathrm{C}$ was performed and amplification was then carried out for 30 cycles. Each cycle was $94^{\circ} \mathrm{C}, 1 \mathrm{~min}$; $50^{\circ} \mathrm{C}, 1 \mathrm{~min} ; 72^{\circ} \mathrm{C}, 1 \mathrm{~min}$. Six microliter samples of the PCR products were analyzed on a $1 \%$ agarose gel in $1 \times$ TAE buffer and products visualized with ethidium bromide.

In situ hybridization. A human felal eye of estimated 17 weeks gestation and $1.5 \mathrm{hr}$ postmortem was fixed in $4 \%$ formaldehyde following the removal of cornea, iris, and lens. Following fixation, the posterior segment of the eye was cut into $1 \times 2 \mathrm{~mm}$ pieces, dehydrated in ethanol, and embedded in diethylene glycol distearate (Polysciences, Warrington, PA). Sections one $\mu \mathrm{m}$ in thickness were cut and handled as previously published (Porrello et al., 1991).

A 233 base pair (bp) fragment containing residues $246-278$ of the coding region was excised by Bam $\mathrm{HI}$ and $\mathrm{Kpn}$ I digestion of human PEDF cDNA (Steele et al., 1993). This fragment was then ligated into the pBluescript II KS-phagemid (Stratagene). The phagemid, with its 233 bp PEDF insert, was linearized by digestion within its multiple cloning site with Sty I or with Bam HI, neither of which have restriction sites in the PEDF fragment. T3 and T7 RNA polymerase were incubated with these DNA templates to generate a sense probe, 264 bases, and an antisense probe, 300 bases in length. Forty of the bases in the sense probe and 67 in the antisense probe were transcribed from vector DNA.

${ }^{35} \mathrm{~S}$-labeled probes were synthesized with a Riboprobe kit (Promega, Madison, WI) according to the manufacturer's instructions. Optimal radiolabel incorporation for a $1 \mu \mathrm{l}$ volume was typically $1 \times 10^{6} \mathrm{DPM}$ for the sense and antisense probes. Hybridization and posthybridization 
of the probes with tissue sections were performed as previously described (Porrello et al., 1991), with the exception that the salt washes were performed at $65^{\circ} \mathrm{C}$. Autoradiograms were photographed under bright-field illumination with Kodak Technical Pan film or under epipolarization with Kodak TMax 400 film (Rapaport et al., 1992).

Northern blot analysis. Total RNA was isolated by the RNAzol B method (Cinna/Biotecx, Friendswood, TX). Total RNA (10 $\mu \mathrm{g}$ ) was diluted in RNA-loading dye containing ethidium bromide (5'Prime$3^{\prime}$ Prime, Inc., Boulder, CO) and electrophoresed for $3 \mathrm{hr}$ at $75 \mathrm{~V}$ in $1 \%$ formaldehyde gels. The RNA was subsequently transferred onto Nytran membranes (Schleicher and Schuell, Keene, NH) using $2 \mathrm{O} \times \mathrm{SSC}$ and Stratagene's Posiblotter (Stratagene, La Jolla, CA). The membranes were UV cross-linked and baked at $80^{\circ} \mathrm{C}$ for $2 \mathrm{hr}$ prior to hybridization. Fifty nanograms of a 667 nt PCR-amplified product of the PEDF cDNA was used as the probe. This was labeled with $\alpha-{ }^{32} \mathrm{P}-\mathrm{dCTP}$ using a Random Prime It Kit 11 (Stratagene). Unincorporated nucleotides were removed using Nuctrap Push columns (Stratagene). The membranes were prehybridized for $30 \mathrm{~min}$ at $68^{\circ} \mathrm{C}$ in QuikHyb solution (Stratagene) followed by hybridization for $1 \mathrm{hr}$ at $68^{\circ} \mathrm{C}$ in the same solution supplemented with $1 \times 10^{6} \mathrm{cpm} / \mathrm{ml}$ radiolabeled $\mathrm{PEDF}$ probe. Posthybridization washes were as follows: $2 \times 15$ minu at $25^{\circ} \mathrm{C}$ wilh $2 \times \mathrm{SSC} / 0.1 \%$ SDS buffer followed by $1 \times 30 \mathrm{~min}$ at $68^{\circ} \mathrm{C}$ with $0.1 \times \mathrm{SSC} / 0.1 \% \mathrm{SDS}$ The hybridized membranes were exposed overnight at $-70^{\circ}$ using XAR-5 X-ray films (Eastman Kodak Co., Rochester, NY) and intensifying screens.

Immunocytochemistry. Monkey RPE cells, cultured in MEM containing $1 \% \mathrm{FCS}$, were seeded onto glass coverslips in 24-well plates. After successive passages, the morphology of confluent or newly attached cells was examined and documented using a Nikon Diaphot microscope. The cells were then fixed in $4 \%$ paraformaldehyde for $15 \mathrm{~min}$ and nonspecific protein binding sites blocked with $1 \mathrm{mg} / \mathrm{ml}$ bovine serum albumin. The PEDF polyclonal antibody was used at a 1:3000 dilution, and cells were reacted with the antibody for $1 \mathrm{hr}$ followed by incubation for $30 \mathrm{~min}$ in an appropriate dilution of FITC-conjugated goat antirabbit IgG. Double-labeling experiments were performed sinilarly, using an actin-monoclonal antibody that recognizes most actins and rhodamine-conjugated goat anti-mouse IgG (Pierce, Rockford, IL). Immunoreactivity was visualized by epitluorescence microscopy using an Olympus BHS microscope equipped with a $40 \times$ UV lens.

\section{Results}

\section{PEDF protein and isoforms}

Coomassie blue staining of proteins in fetal human RPE-CM separated by SDS-PAGE shows a prominent $50 \mathrm{kDa}$ PEDF band, typically running as a doublet (Fig. 1, lane 2) that is absent from nonconditioned medium (lane 1). We have previously shown this protein to be the neurotrophic factor in the fetal RPECM (Tombran-Tink et al., 1991). By two-dimensional gel analysis, at least four isoforms of the purified human PEDF protein are detected by Coomassie blue staining (Fig. 2A). The spots vary only slightly in apparent molecular size; the four most prominent species have apparent pIs of $6.0,6.2,6.4$, and 6.6. The PEDF polyclonal antibody recognizes all four isoforms of this protein and possibly two others in both human RPE-CM and bovine IPM, as shown by Western blot analysis of the transblotted 2-D gels (Fig. 2B,C).

\section{PEDF mRNA expression in human fetal RPE cells in vivo}

The effect of PEDF on Y-79 retinoblastoma cell differentiation was first demonstrated with conditioned medium from human fetal RPE cells. Thus, we performed in situ hybridization studies on a specimen of fetal human retina-RPE at a developmental age similar to that of the cells used for fetal human RPE culture (i.e., 17 weeks of gestation). Tissue hybridized with antisense probes under high stringency $\left(65^{\circ} \mathrm{C}\right)$ showed specific binding of the probe to the RPE cell layer (Fig. $3 A-C$ ). The retinal neuroblastic layer, which contains a well differentiated ganglion cell layer at this developmental stage but is otherwise relatively undifferentiated, was not labeled above background. Control hy- bridizations, using a sense probe, resulted in labeling only at the background level (Fig. 3D).

Due to heavy melanization of the RPE, it was necessary to assess the true silver grain density over this cell layer. Epipolarization microscopy was used for this purpose. This method, unlike dark-field microscopy, reveals only the silver grains and not the underlying melanin granules (Rapaport et al., 1992). In Figure 3, $B$ and $C$ represent bright-field and epipolarization illumination, respectively, of identical areas of the retina-RPE complex and demonstrate the relatively heavy concentration of silver grains over the RPE.

\section{PEDF secretion}

By Western blot analysis, an immunoreactive doublet at $50 \mathrm{kDa}$, comparable to the protein seen in CM from human fetal RPE cells (Fig. 1), is readily detected by anti-PEDF in conditioned medium from RPE cells and in soluble washes of IPM from a number of species (Fig. $4 A$ ). The $50 \mathrm{kDa}$ protein is found in RPE-CM from both fetal and adult human RPE cells (lanes 1 and 2, respectively). CM from RPE cells of young adult monkey (third passage in culture) and from chick embryo (in primary culture) also show $50 \mathrm{kDa}$ bands identified by the human PEDF polyclonal antibody (lanes 3 and 4 , respectively). A positive PEDF band is also detected in soluble washes of adult human IPM (lane 5) and in IPM from fetal (lane 6) and adult (lane 7) cow. The PEDF doublet is most often clearly defined in lanes with lower concentrations of protein (lanes 3-7). The presence of PEDF in the IPM indicates that it is secreted in vivo in both fetal and young adult eyes where it could influence neuronal differentiation and/or survival of retinal neurons.

Interestingly, a $50 \mathrm{kDa}$ protein was not detected in total cellular extracts of 10th passage RPE cells (Fig. 4A, lane 8). To better examine the effect of cellular aging, samples of CM from RPE cells up to 15 passages in culture were examined (Fig. $4 B$ ). PEDF was found to be secreted in abundance by RPE cells in their first and second passages (Fig. 4B, lanes 1, 2, respectively) and at the third passage (Fig. $4 A$, lane 3 ), but only weakly by these cells in the fifth passage (Fig. $4 B$, lane 3 ). The protein is not detected in the conditioned medium of RPE cells at the 10 th or 15 th passages (Fig. 4B, lanes 4, 5, respectively). The blot shown in Figure $4 B$ was developed for a longer period of time than usual to demonstrate that loading of protein was uniform in all lanes and that only the specific $50 \mathrm{kDa}$ band of PEDF is undetectable in the older cultures. Thus, PEDF secretion by RPE cells decreases dramatically and specifically in an age-related manner. This decrease is paralleled by marked changes in RPE cell morphology and is inversely related to cell proliferation. During the first few cell passages, the cells divide rapidly and form relatively confluent monolayers within 24-48 hr. Most of these cells are compact, hexagonal-shaped cells that are epithelial in appearance. Fully confluent cultures are present about 5-7 d after passage in these cases (Fig. $5 A$ ). After about the fifth passage, however, cell proliferation slows (confluency reached at 1 to 2 weeks), and the cells begin to assume a larger, more elongated, spindle-like appearance (Fig. 5B). By about passage 810 , RPE cells are all fibroblastic in appearance (Fig. $5 C$ ). Division of these cells is very slow, with a dramatic loss of proliferative potential. Confluency is reached only after the fourth week in culture. Importantly, these 10 th to 15 th passage cells are also unresponsive to the addition of serum ( $10 \% \mathrm{FCS})$. These results are similar to those found in well-known aging models such as 


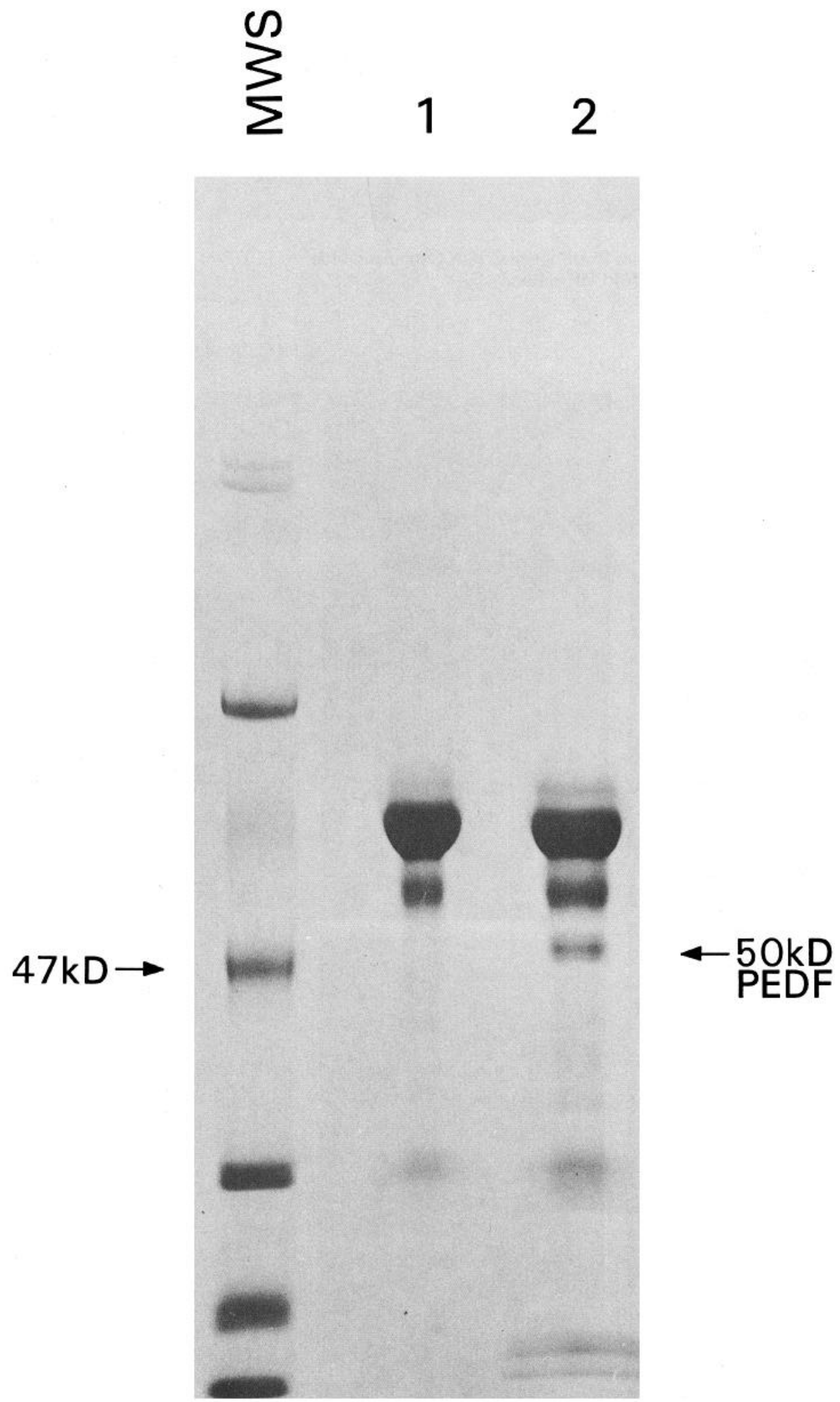

Figure 1. SDS-PAGE analysis of proteins secreted by cultured human fetal RPE cells. Lane 1, proteins in control nonconditioned medium. Lane 2, proteins in medium conditioned for $7 \mathrm{~d}$ by fetal RPE cells. $M$, molecular weight standards. Proteins are stained with Coomassie blue.

the cultured WI-38 fibroblast cell system (Pignolo et al., 1993) and thus the RPE cells at later passage can be operationally defined as "senescent."

We also were interested in seeing if PEDF could be detected within the early-passage, confluent monkey RPE cells (i.e., intracellularly) and in cell extracts of freshly dissected bovine RPE and retinal tissues (Fig. 4B, lanes 6-8, respectively). Surprisingly, the PEDF antibody detects a doublet (as often seen for native PEDF) migrating at about $36 \mathrm{kDa}$ rather than at $50 \mathrm{kDa}$ in both the cultured RPE cells and tissue extracts. The finding of low levels of the $36 \mathrm{kDa}$ species in extracts of the neural retina awaits confirmation by immunocytochemistry in situ since it 

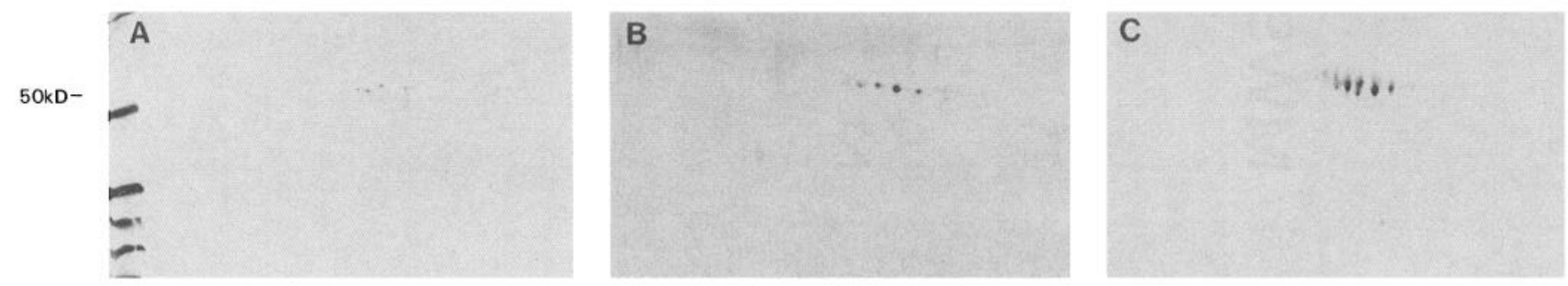

Figure 2. 2-D gel electrophoresis of PEDF isoforms. A, Purified human PEDF stained with Coomassie blue. B, PEDF in CM from human RPE cells detected by PEDF antibody. $C$, PEDF in bovine IPM detected with PEDF antibody.
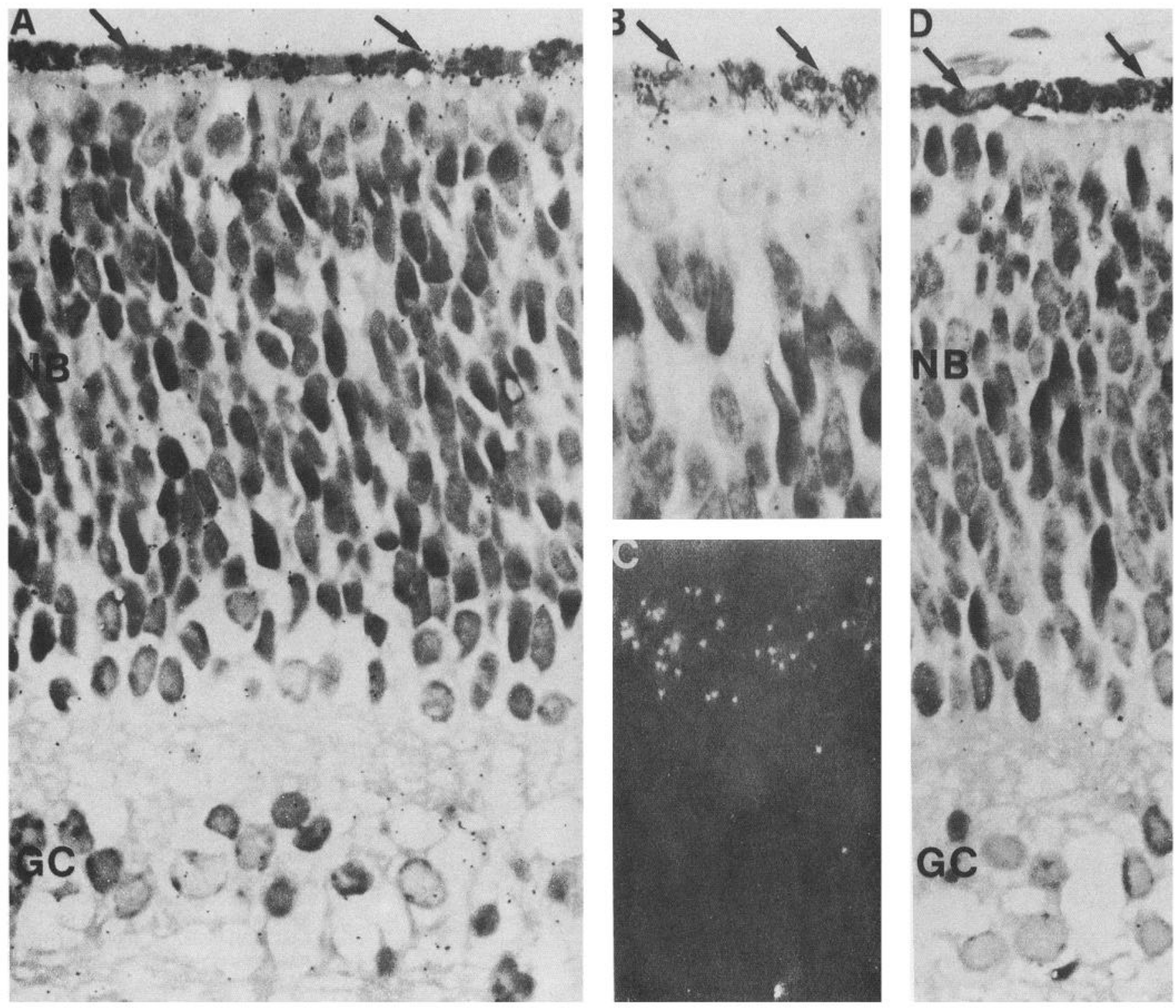

Figure 3. In situ hybridization autoradiograms of human fetal retina at 17 weeks of gestation. The autoradiograms were photographed under bright-field illumination $(A, B$, and $D)$ or under epipolarization illumination $(C)$. $A$, Retinal section incubated with the radioactive antisense probe reveals the concentration of silver grains above background over the retinal pigment epithelium (arrows). The neuroblastic (NB) layer, ganglion cell $(G C)$ layer, and other regions of the neurosensory layer were not consistently labeled above background. B, Retinal pigment epithelium (arrows) under higher magnification reveals more detail, although some silver grains remain obscured by underlying melanin granules. $C$, Epipolarization microscopy of the same area as that shown in $B$ reveals all of the silver grains over the RPE. $D$, Retinal sections incubated with the radioactive sense probe bound only background levels of radioactivity, as indicated by the low density of silver grains over the RPE (arrows). Autoradiograms were exposed for $12 \mathrm{~d}$. Magnification: $A$ and $D, 800 \times ; B$ and $C, 1360 \times$. 


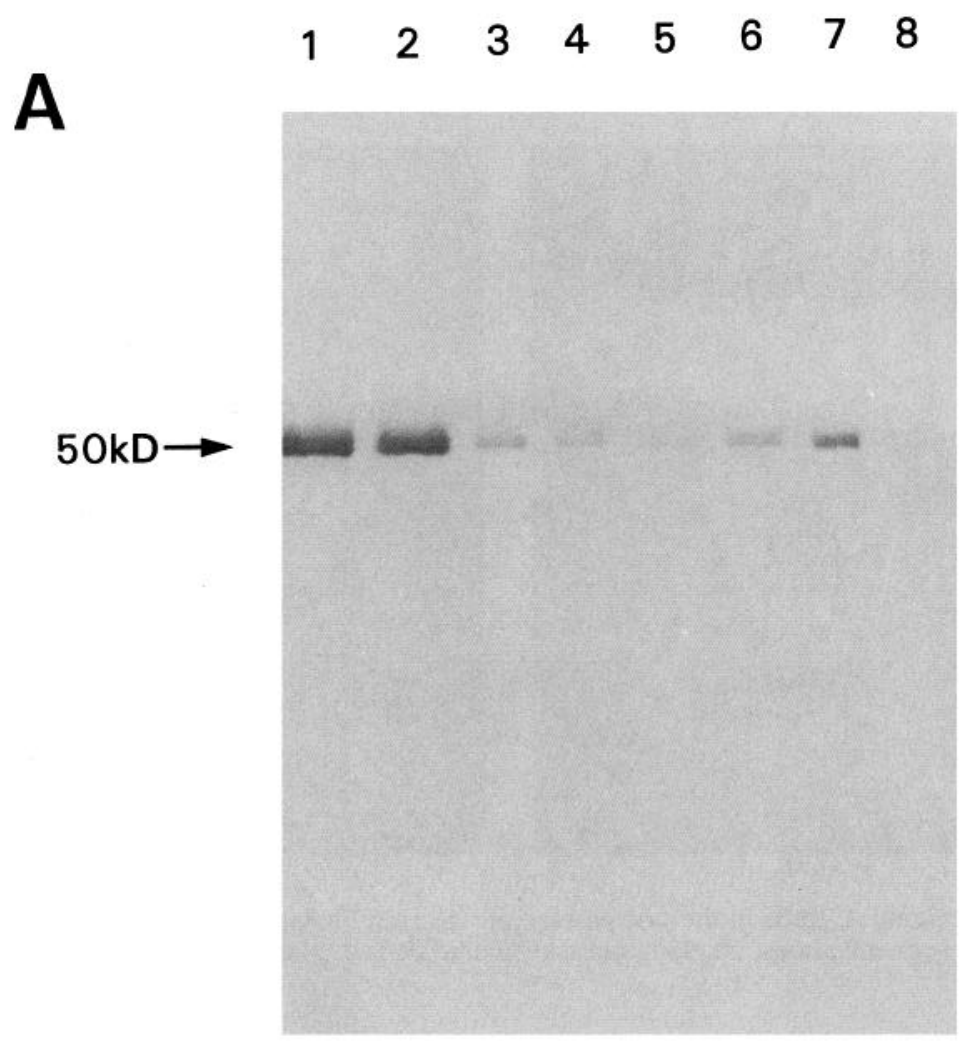

B

Figure 4, A, Western blot of samples of RPE cell-conditioned medium ( $C M$ ) and of soluble proteins from the interphotoreceptor matrix (IPM) and monkey RPE cell extract. Lane 1, human fetal RPE-CM. Lane 2, human adult RPE-CM. Lane 3, young adult monkey RPE-CM (third passage in culture). Lane 4, chick embryo RPE-CM. Lane 5 , adult human IPM. Lane 6, fetal bovine IPM. Lane 7 , adult bovine IPM. Lane 8, young adult monkey RPE cell soluble extract (10th passage in culture). $B$, Western blot analysis of samples of monkey RPE-CM conditioned for $7 \mathrm{~d}$ by confluent monolayer cultures after successive cell passages and analysis of RPE and retinal cell extracts. Lanes $1-5$, conditioned medium from cells after 1 st, 2 nd, 5th, 10th, and 15th passages, respectively. Lanes $6-8$, second passage RPE cell extract, adult bovine RPE, and retinal cell extracts, respectively. $M$, molecular weight standards.

would be expected that small amounts of RPE contamination would be present in the dissected retinal tissue. In any event, our findings raise the possibility that some PEDF is retained intracellularly in RPE cells or is taken back up from the medium or IPM as a lower molecular weight species. It is also interesting to note here that, similar to the $50 \mathrm{kDa}$ secreted protein, the 36 $\mathrm{kDa}$ species is only detected in early passage RPE cells (Fig. $4 B$, lane 6 ) and is absent by the 10 th passage (Fig. $4 A$, lane 8 ). Thus, species of both molecular sizes disappear in parallel with culture age.

\section{mRNA analysis}

Figure 6 shows that, using primers 601 and 499, which encompass a $1.47 \mathrm{~kb}$ sequence of the PEDF message, a single product of approximately $1.5 \mathrm{~kb}$ is amplified from cultured fetal human cells (lane 1), cultured young adult monkey cells (lane 2), and freshly isolated bovine RPE cells (lane 3). By Northern blot analysis, a $1.5 \mathrm{~kb}$ band is also detected with the $667 \mathrm{bp} \mathrm{PCR}$ amplified PEDF probe in cultures of fetal and adult human RPE cells as well as in RPE cell explants (Fig. 6B, lanes 1-3, respectively). Relatively more PEDF mRNA is seen in the fetal 


\section{A.}

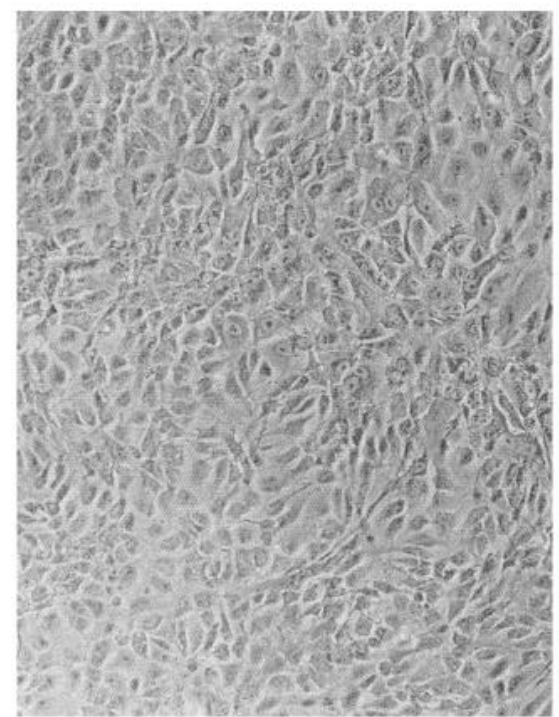

B.

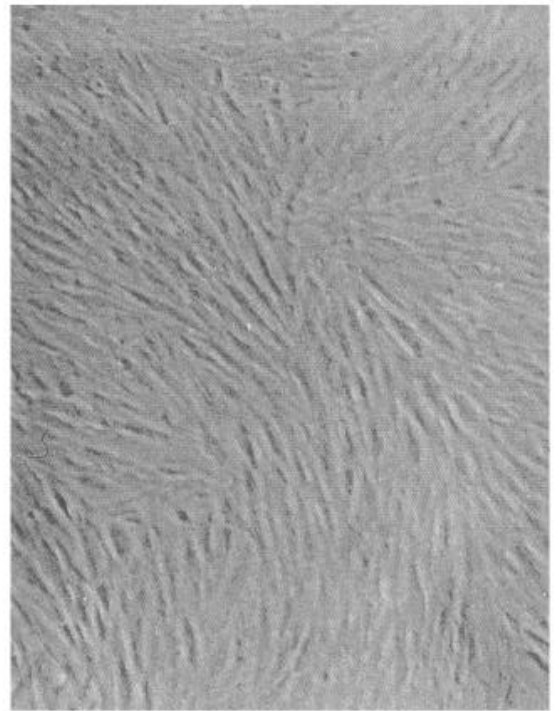

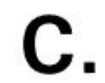

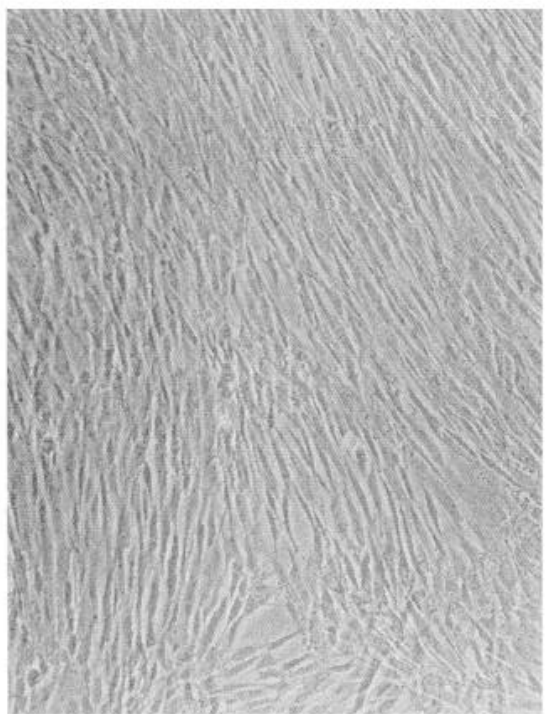

Figure 5. Morphology of confluent monkey RPE cells in culture. A, Cells in the first passage are generally compact and hexagonal. B, Cells in the fifth passage are more elongated. $C$, Cells in the 10th passage are almost all elongated and spindle shaped. Magnification, $250 \times$.

RPE cell explants as compared to cultured cells. No difference is seen in the size of the messages under any of the conditions (fetal vs adult, human vs monkey or cow). Thus, by Western (both one- and two-dimensional) and Northern blot analyses and by PCR, the molecular sizes of the secreted $50 \mathrm{kDa}$ protein and its mRNA appear to be similar in human, monkey, and cow. Seeing only one mRNA transcript at $1.5 \mathrm{~kb}$ also argues for the fact that the $36 \mathrm{kDa}$ PEDF protein species arises from protein processing rather than alternative mRNA splicing.

Figure $6 C$ (top) shows an ethidium bromide-stained agarose gel on which $5 \mu \mathrm{g}$ of total RNA from monkey retina and from first and 10th passage monkey RPE cells were electrophoresed (lanes 1-3, respectively). The bottom panel is a replica blot of this gel hybridized with radioactively labeled PEDF probe. A weak hybridization signal is seen in the lane containing total RNA from retina (lane 1 ). This may be due to small amounts of RPE that adhere to the retinal tissue during dissection. A much more prominent $1.5 \mathrm{~kb}$ transcript band is present in the early (first) passage monkey RPE cells (lane 2), while no transcript is detected in the late (10th) passage RPE cells (lane 3). Thus, similar to the secretion pattern of PEDF protein after successive RPE cell passages, late-passage monkey RPE cells do not transcribe PEDF mRNA.

\section{Intracellular localization of PEDF}

Having identified a $36 \mathrm{kDa}$, immunoreactive species in RPE cell extracts by Western blot analysis, we thought it of interest to examine cultured monkey RPE cells (third passage) by immunofluorescence microscopy for the intracellular localization of PEDF-like reactivity. In well-attached cells (5-10 d postattachment), immunofluorescence is seen in association with cytoskeletal elements and with the nucleus (Fig. 7A). Earlier in attachment ( $2 \mathrm{~d}$ after seeding), staining is concentrated around the nucleus and is of a granular nature (Fig. $7 B$ ). The protein is also associated with a fibrous cytoskeletal-like network (Fig. 7B,C), When early-passage monkey RPE cells are examined soon after seeding (1-2 hr), discrete localization of the PEDF protein is seen at the tips of many processes of RPE cells (Fig. $7 D-F$ ). Similar to the dramatic decrease seen in PEDF secretion and transcription with successive cell passages, no immunoreactivity with the PEDF polyclonal antibody is detected in cultured monkey RPE cells after the 10th passage (not shown).

To further examine the association of PEDF immunoreactivity with cytoskeletal elements within the cytoplasm, we analyzed the structures by double labeling using anti-PEDF (Fig. 8A) and an antibody to human actin (Fig. $8 B$ ) and found that the pattern of staining for both antibodies was very similar. Both antibodies colocalize around the nucleus and to cytoskeletal strands in the cytoplasm. Concentration of both antibodies is also seen at the tip of a pseudopod, which is probably yet in the process of attachment. Because of PEDF's apparent association with cytoskeletal structures, possibly actin microfilaments, we addressed the possibility of antibody cross-reactivity with actin. Figure $9 \mathrm{~A}$ shows the migrational patterns of proteins in RPE-CM and of purified samples of $\alpha-1$ antitrypsin and actin. Figure $9 B$ shows a Western replica blot of the gel in Figure $9 A$ that demonstrates that anti-PEDF does not bind to purified actin (lane 3). Only a positive PEDF band at $50 \mathrm{kDa}$ is observed in RPE conditioned medium (Fig. 9B, lane 1). The antibody also does not recognize human $\alpha$-1-antitrypsin, a homologous member of the serpin supergene family and the most likely contamination in preparations (Fig. 9B, lane 2). It thus seems that the PEDF antibody specifically recognizes and binds to PEDF (50 and/or $36 \mathrm{kDa}$ forms) associated with areas such as the intracellular actin cytoskeletal network of the RPE cells, but does not seem to bind directly to purified actin itself, at least as assessed by Western blot.

\section{Discussion}

The RPE has long been thought to influence development of the neural retina. For example, cells of a more neural character are induced in retinal cells cocultured with RPE cells (Israel et al., 1978). Similarly, a high level of retinal organization (Volmer et 

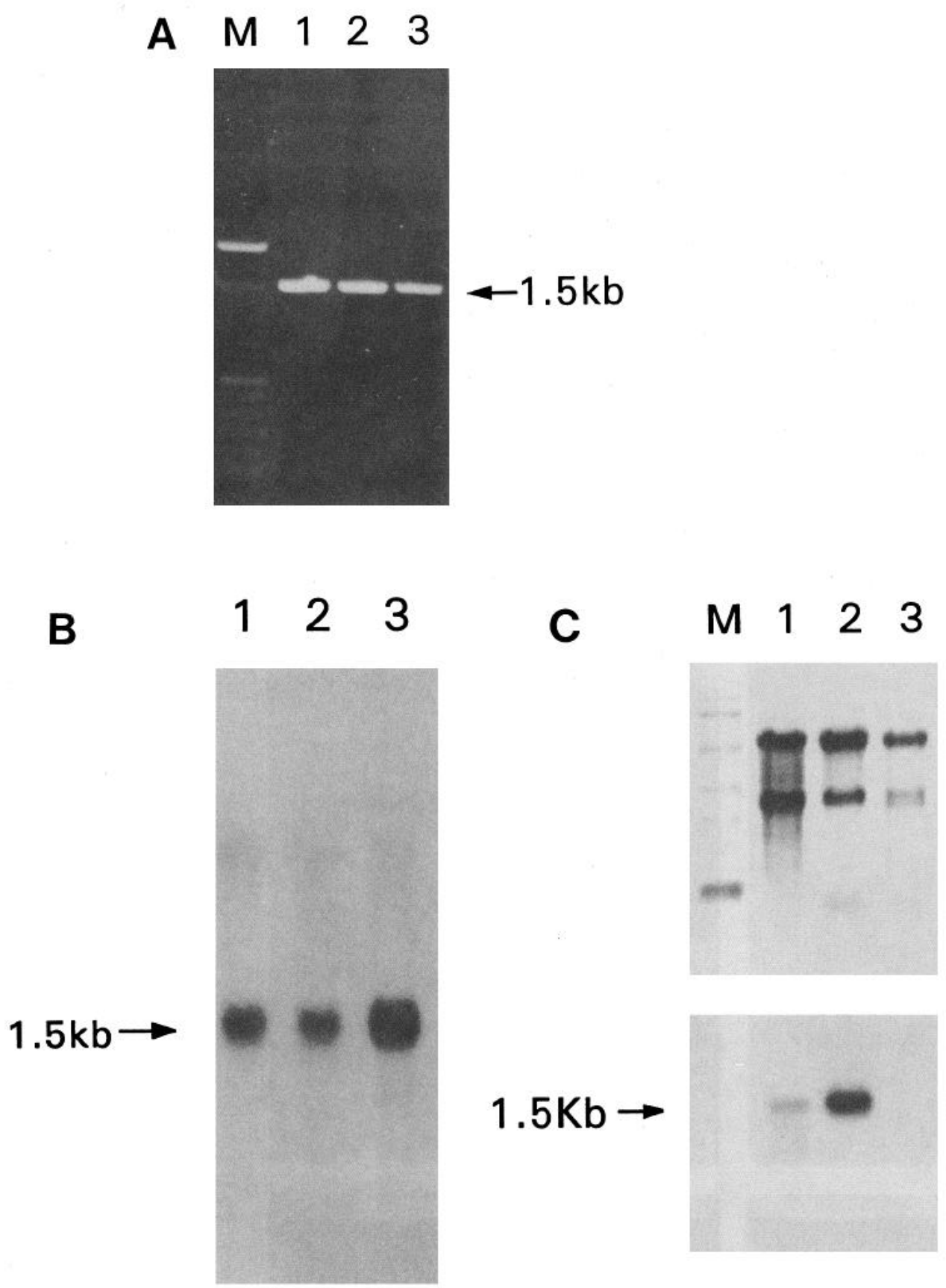

Figure 6. Analyses of PEDF mRNA. $A$, PCR assay using primers 601:499. Lane 1, cultured fetal human RPE cells. Lane 2, cultured adult monkey RPE cells (second passage). Lane 3, adult bovine RPE cells. $M$, molecular weight standards. $B$, Northern blot analysis using a radioactively labeled 667 bp PEDF cDNA. Lane 1, cultured fetal human RPE cells. Lane 2, cultured adult human RPE cells. Lane 3, fetal human primary RPE cell explants. $C:$ Top, Agarose gel containing $5 \mathrm{pg}$ of total RNA in each lane stained with ethidium bromide. Lanes 1-3, monkey retina, first passage monkey RPE cells, 10th passage monkey RPE cells, respectively. Bottom, Blot of gel in the top panel hybridized with radioactively labeled PEDF cDNA probe. $M$, molecular weight standards. al., 1984) and the maintenance of cell growth and differentiation of chicken retinal explants (Liu et al., 1988) are reported in cultures containing RPE cells. The induction of neuronal differentiation of photoreceptor cells is also seen in retinal cultures supplemented with medium conditioned by RPE cells (Spoerri et al., 1988; Liu et al., 1990; Gaur et al., 1992). Most recently, we have shown that soluble extracts of adult bovine and monkey IPM exhibit a potent neurotrophic activity similar to the effects seen with purified PEDF from fetal RPE cells (Tombran-Tink et al., 1992) when tested in a retinoblastoma model system.

Although PEDF is a major secretory product of human fetal RPE cells in culture (Fig. 1; Tombran-Tink et al., 1991), it has not been clear if PEDF is secreted by RPE cells in vivo and is actually present in the fetal and/or adult IPM. Our present study demonstrates that cultured RPE cells from embryonic chick as well as from adult human and monkey secrete PEDF. Moreover, PEDF is clearly present in soluble extracts of IPM derived from the fetal cow as well as from the adult cow and human. Although PEDF is readily detected in CM from monkey RPE cells in their first through third passage, only a small amount is present in the CM of fifth-passage RPE cells, and no PEDF is found within RPE cells or in the CM after their 10th passage. In addition, PEDF mRNA is only seen in early passage- and not in late passage-RPE cells. Thus, Western and Northern blot analyses as well as immunocytochemical studies demonstrate a marked downregulation of PEDF expression in older RPE cells where cell proliferation is markedly slowed and the cells do not respond to mitogenic stimulation with serum. Moreover, there is a close temporal relationship between the loss of PEDF expression and dramatic morphological changes in late-passage mon- 

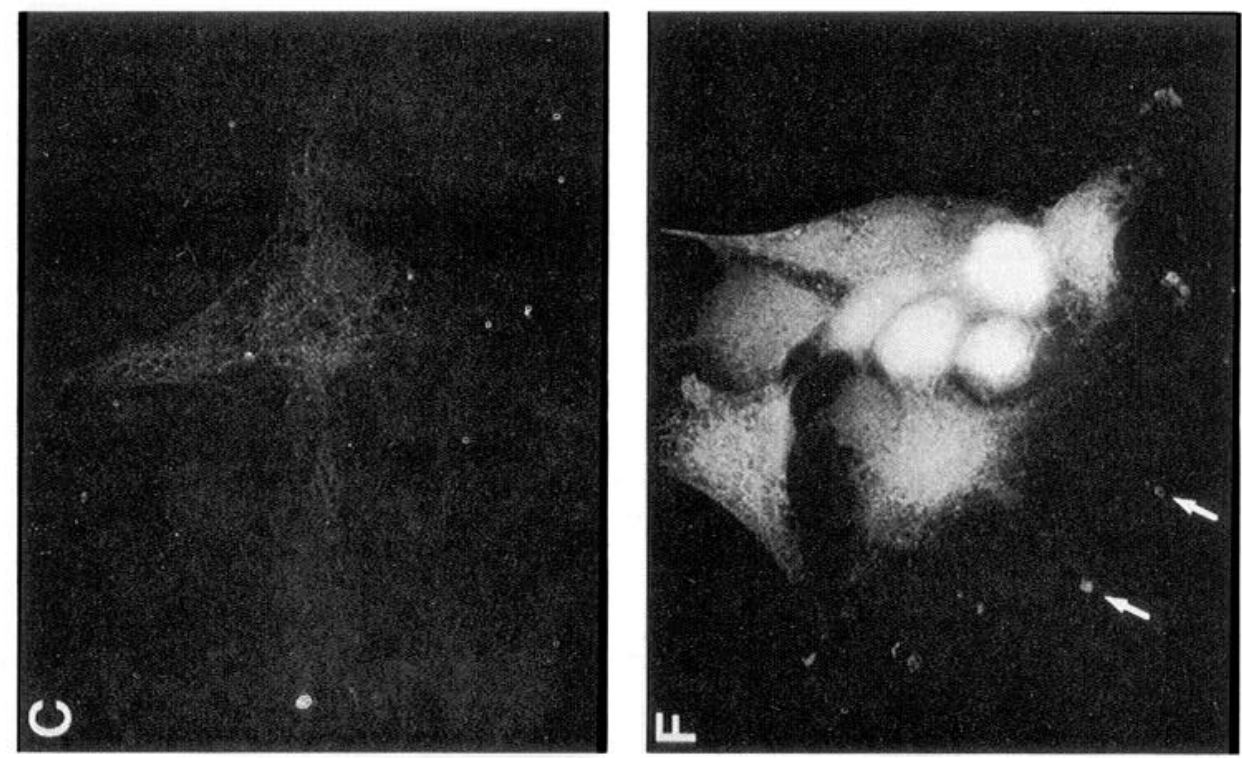

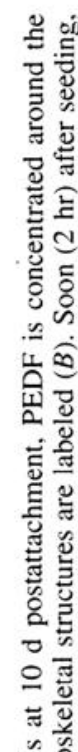
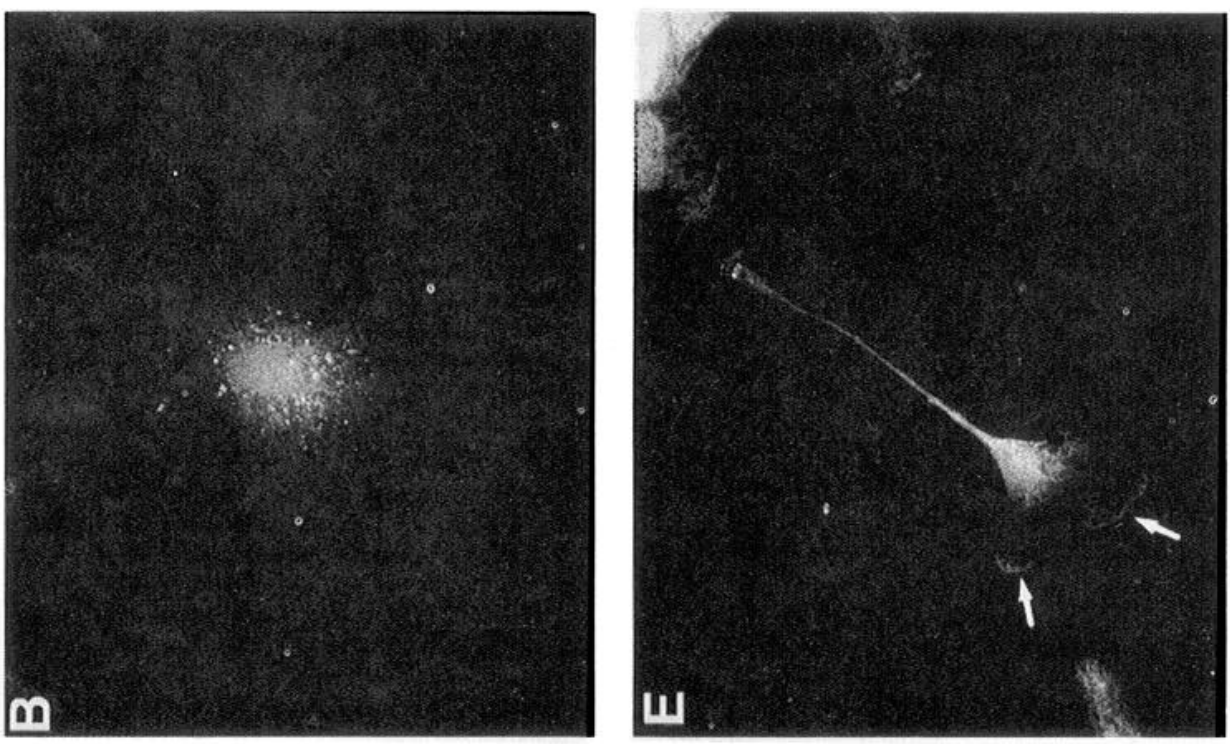

엉

氖

胥

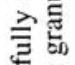

드

象莺

띵ํํ

딘

플

总氖

品

윰도

颉

들

פல்

4 웅

똥
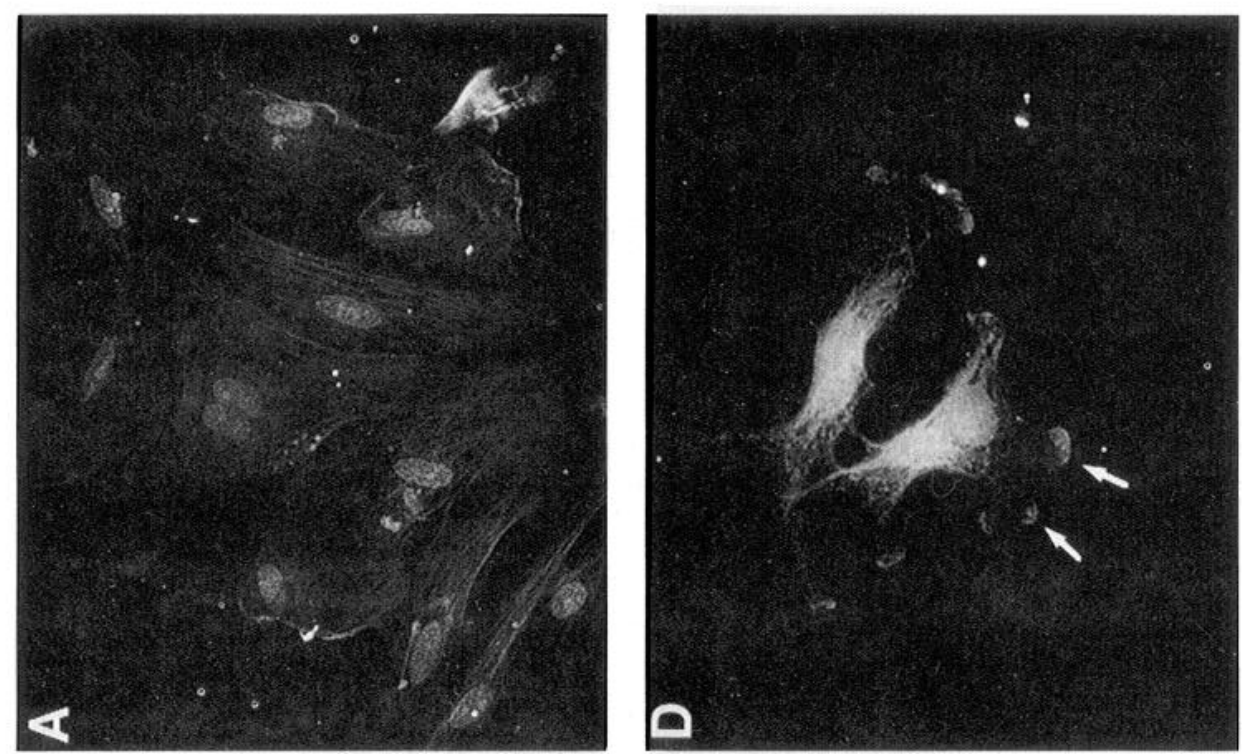

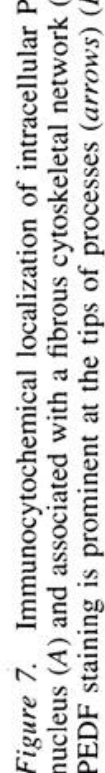



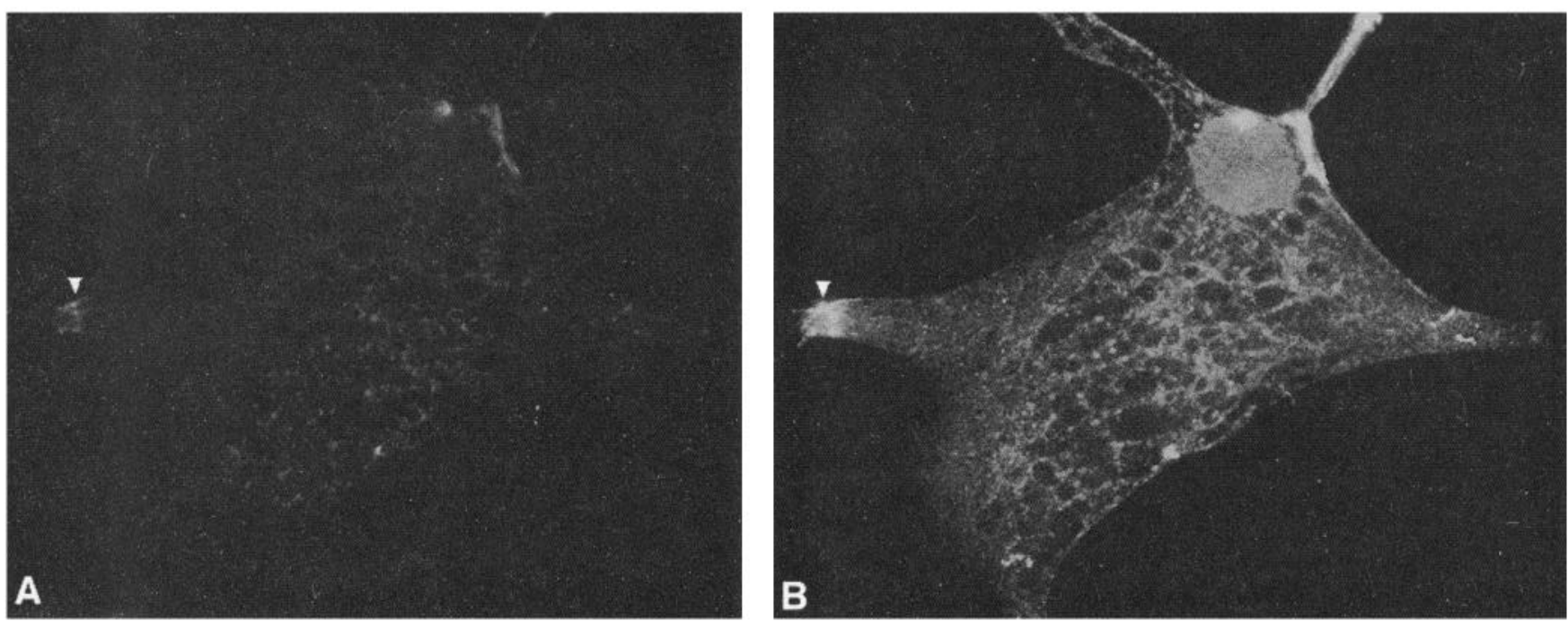

Figure 8. Comparative immunocytochemical localization of $A, \operatorname{PEDF}$ (fluorescein) and $B$ actin (rhodamine) in the same cells. The double labeling pattern demonstrates binding to similar structures by PEDF and actin antibodies. Arrowheads point to PEDF and actin at the tip of a pseudopod. Magnification, $650 \times$.

key RPE cells where the cells change from an epithelioid to a fibroblastic appearance. Age-related changes in RPE cell morphology, particularly in cytoskeletal structure, are well documented both in vivo (Mishima and Hasebe, 1978; Katz and Robison, 1984) and in vitro (Grisanti and Guidry, 1995). Interestingly, Grisanti and Guidry (1995) have recently demonstrated an age-related "transdifferentiation" of cultured porcine RPE cells where the cells lose their epithelial characteristics in late passage and begin to express mesenchymal markers. Although it is not yet clear if loss of PEDF expression precedes or merely accompanies the morphological changes seen in our cultures, studies are underway to determine if a similar pattern is apparent in the aging human RPE in vivo. However, our results on cul- tured RPE cells are in accord with studies from Pignolo et al. (1993), who have reported that mRNA from PEDF (called EPC1) could be found only in confluent, young WI-38 fibroblast cells in culture with no transcript detected in senescent cells.

In a similar vein, we have previously reported that PEDF mRNA was undetectable in fully differentiated Y-79 retinoblastoma cells, although readily seen in their rapidly dividing, nondifferentiated counterparts (Tombran-Tink et al., 1994). It is also of interest that CM from cultured human fetal RPE cells that contains PEDF has been found to prolong the life of neuronally differentiated Y-79 cells grown under serum-free conditions (Tombran-Tink and Johnson, 1989) as well as rat cerebellar granule cells in primary culture (Taniwaki et al., 1994). Al-
A.

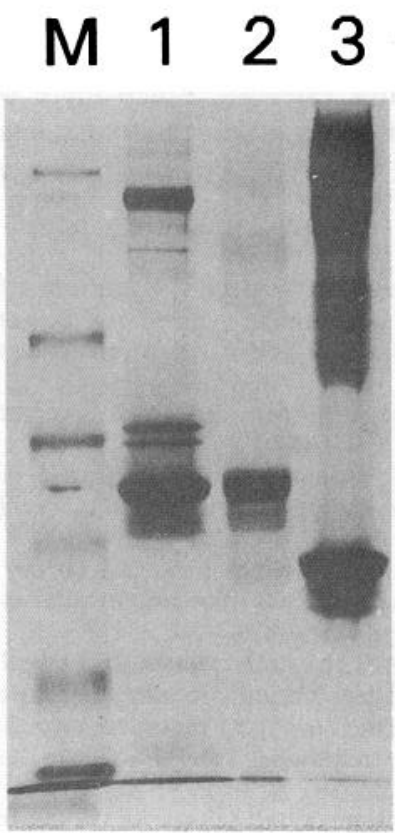

B.
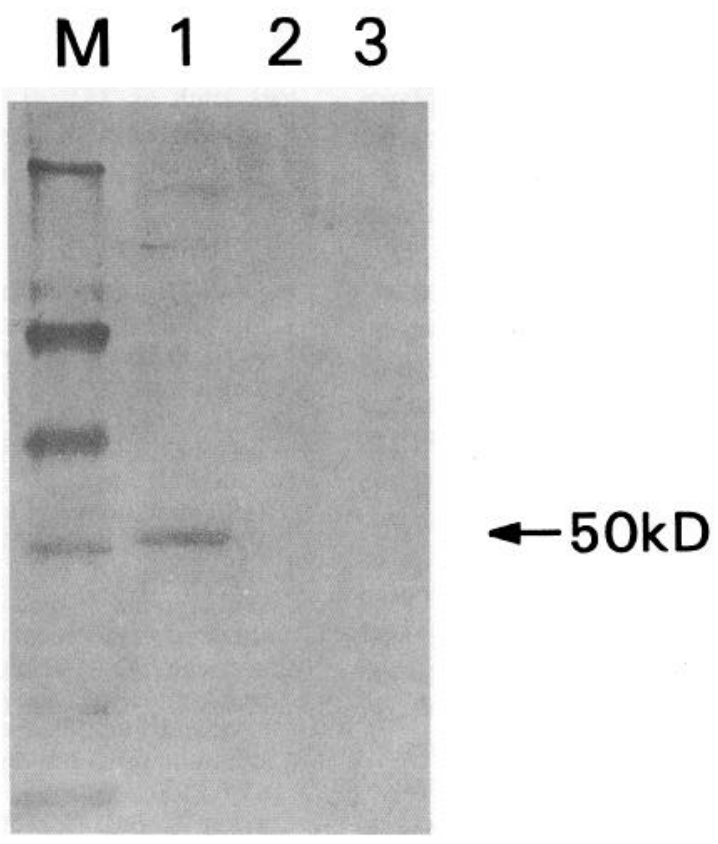

Figure 9. A, Coomassie blue staining of protein gel electrophoretic patterns of human fetal RPE-CM (lane 1) purified human actin (lane 2), and purified human $\alpha$-1-antitrypsin (lane 3). $M$, molecular weight standards. $B$, Western blot analysis of a replica gel showing that the PEDF polyclonal antibody only recognizes PEDF protein found in the RPE-CM (lane 1) and does not bind to either actin (lane 2 ) or $\alpha$-1-antitrypsin (lane 3). 
though further work will have to be done on this phenomenon, our findings, along with those of Pignolo et al., (1993) raises the interesting possibility that the presence of PEDF could promote cell survival of mature neurons, and the lack thereof could be a general marker for terminal differentiation and/or senescence in different cell types. These results also form a rationale for our present finding that PEDF is synthesized and secreted by adult RPE cells as well as during the fetal period. Specifically, PEDF could act as a differentiating factor in early retinogenesis and then a neuronal survival factor for mature photoreceptor neurons at least until RPE cell senescence in vivo. Our present work now shows that PEDF could actually participate in retinogenesis since (1) PEDF mRNA is present in human fetal RPE cells by at least 17 weeks of gestation, (2) PEDF protein is readily detectable in soluble IPM washes of fetal bovine eyes, and (3) PEDF has a dramatic neurotrophic effect on Y-79 retinoblastoma cells (Tombran-Tink et al., 1991), a transformed counterpart of developing retinoblasts.

Several isoforms of the $50 \mathrm{kDa}$ secreted PEDF protein are observed. The multiple variants seen in 2-D electrophoresis probably indicate that posttranslational modification is an integral part of PEDF synthesis and processing. Once secreted, the $50 \mathrm{kDa}$ form of PEDF appears to be relatively stable, possibly due to lack of appropriate degradative activity in the IPM in vivo and the culture medium in vitro. Since PEDF is found in relative abundance in the IPM, however, and since the gene exhibits a putative leader sequence (Steele et al., 1993), localization of the immunoreactive $36 \mathrm{kDa}$ form of the protein intracellularly was surprising. Specificity of the PEDF antibody does not seem to be in question, since it only recognizes PEDF in the IPM and does not recognize the archetypical serpin, human $\alpha-1$ antitrypsin, which could be present as a contaminant. In RPE cells, it appears that a portion of the translated product, even though secreted as a $50 \mathrm{kDa}$ protein, is retained intracellularly or is taken back up with processing as a $36 \mathrm{kDa}$ protein. The simplest of several possihle explanations of these results is that a small amount of secreted PEDF reenters the RPE cell either as the $36 \mathrm{kDa}$ species or with subsequent, intracellular cleavage of the $50 \mathrm{kDa}$ form. This process could be specific, since smaller degraded products are not observed intracellularly or extracellularly and the $36 \mathrm{kDa}$ protein retains its characteristic doublet appearance on gels. The mRNA for PEDF is readily detected in cultured human fetal and adult RPE cells and in RPE explants and is observed as a single $1.5 \mathrm{~kb}$ transcript. No alternative transcripts are detected that could account for the $36 \mathrm{kDa}$ species. N-terminal amino acid analyses of the $36 \mathrm{kDa}$ protein may help to clarify this point in the future.

In newly seeded RPE cells that are in the process of attaching, PEDF is concentrated in lamellopodial ruffles and focal adhesion points of pscudopods. This suggests a functional association of the protein with leading edge substructures involved in the attachment phenomenon. In fully attached cultured cells, PEDF immunoreactivity is localized to specific structures including the nucleus, large and small granules concentrated around the nucleus, and a fibrous cytoskeletal network that includes actin as a component. Since little of the $50 \mathrm{kDa}$ PEDF protein is detected in RPE cell extracts, we assume that it is secreted rapidly into the medium/IPM. However, the granular staining seen around the nucleus under most conditions could be due to the antibody interaction with small amounts of the $50 \mathrm{kDa}$ PEDF in secretory granules. In contrast, the more extensive cytoskeletal and nuclear immunoreactivity is most likely due to the $36 \mathrm{kDa}$ species, since this species is the only one identified on Western blots of cell lysates. The fact that a secreted protein like PEDF can also be found intracellularly in the cytosol is not unique. Secreted proteins like cathepsin $D$ and acid phosphatase have been reported to be cytosolic components of many cell types (Zeillinger et al., 1992; Brouillet et al., 1993; Dissing et al., 1993). Other serpins are thought to be "dualistic molecules" in that they can be either secreted or cytoplasmic (Remold-O'Donnell, 1993). The association of PEDF (probably in the $36 \mathrm{kDa}$ form) with cytoskeletal structures and its colocalization with actin suggests that, at least intracellularly, it may be a microfilament-binding protein. Thus, PEDF could be involved in the assembly and/or stability of cytoskeletal structures. This is a reasonable working hypothesis since PEDF is (1) concentrated in developing lamellopodial ruffles during early RPE cell attachment, (2) associated with the actin-containing cytoskeleton in mature cells, and (3) lost in older cells that undergo extensive morphological changes. Antibodies to different areas of the PEDF molecule are currently in production to better determine the form of PEDF that is associated with the different subcellular structures.

Although the serpin gene family is large and many of its members have been intensively studied (Marshall, 1993), little is known about the presence of serpins in the CNS or their action(s) on neural tissues. A notable exception, however, is gliaderived nexin (also called protease nexin-1), a $43 \mathrm{kDa}$ product of several cell types including glia (Mansuy et al., 1993) and certain brain neurons (Reinhard et al., 1994) that induces neurite outgrowth in cultured neuroblastoma cells. Monard (1988) and others have hypothesized that protease inhibitors such as GDN could play a role in the development and functioning of neural tissues. The presence of PEDF in the extracellular matrix of the neural retina at both fetal and adult ages in vivo as well as its neurite-promoting ability in retinoblastoma cell cultures (Tombran-Tink et al., 1991; Steele et al., 1993) indicatc that PEDF could be involved in similar processes. Moreover, its intracellular localization coupled with its loss in senescent fibroblasts (Pignolo et al., 1993), differentiated retinoblastoma cells (Tombran-Tink et al., 1994), and late-passage RPE cells as shown in the current work indicates that PEDF could be involved in several other important cellular functions such as terminal differentiation and aging. It is not unusual for a protein to be multifunctional in nature; the p53 and p1O3 proteins and growth factors such as TGF- $\beta$ fall into this category. Much more work, however, will be needed to determine the putative role(s) of PEDF in cellular development, mature functioning, and aging.

\section{References}

Becerra SP, Palmer I, Kumar A, Steele F, Shiloach J, Notario V, Chader GJ (1993) Overexpression of fetal human pigment epithelium-derived factor in $E$. coli: a functionally active neurotrophic factor. J Biol Chem 268:23148-23156.

Bok D (1985) Retinal photoreceptor-pigment epithelium interactions. Invest Ophthalmol Vis Sci 26:1659-1694.

Brouillet JP, Spyratos F, Fauque G, Maudelonde T, Rochfort H (1993) Immunoradiometric assay of pro-cathepsin D in breast cancer. Eur J Cancer 29:1248-1251.

Campochiaro PA, Sugg R, Grotendorst G, Hjelmeland LM (1989) Retinal pigment epithelial cells produce PDGF-like proteins and secrete them into their medium. Exp Eye Res 49:217-227.

Campochiaro PA, Mimuro J, Sugg R, Lostoff DJ (1989) Retinal pigment epithelial cells produce a latent fibrinolytic inhibitor that is an tigenically and biochemically related to type I plasminogen activator inhibitor produced by vascular endothelial cells. Exp Eye Res 49: 195-203.

Carlson A, Bok D (1992) Promotion of the release of 11-cis, retinal 
from cultured retinal pigment epithelium by interphotoreceptor retinoid-binding protein. Biochemistry 31:9056-9062.

Cunha-Vaz JG (1979) The blood-ocular barriers. Surv Ophthalmol 23: 279-296.

Dissing J, Rangaard B, Christensen U (1993) Activity modulation of the fast and slow isozymes of human cytosolic low- molecular-weight acid phosphatase (ACP1) by purines. Biochim Biophys Acta 1162: 275-282.

Elner UM, Schaffner T, Taylor, Glagou KS (1981) Immunophagocytic properties of retinal pigment epithelial cells. Science 211:74-76.

Feency-Burns L (1988) The pigments of the retinal pigment epithelium. Curr Top Eye Res 2:120-178.

Flannery JG, O'Day W, Pfeffer BA, Horwitz J, Bok D (1990) Uptake, processing and release of retinoids by cultured human retinal pigment epithelium. Exp Eye Res 51:717-728.

Gaur VP, Liu Y, Turner JE, (1992) RPE conditioned medium stimulates photoreceptor cell survival, neurite outgrowth and differentiation in vitro. Exp Eye Res 54:645-659.

Grisanti S, Guidry C (1995) Transdifferentiation of retinal pigment epithelial cells from epithelial to mesenchymal phenotype. Invest Ophthalmol Vis Sci 36:391-405.

Hageman GS, Johnson LV (1991) Structure, composition and function of the retinal interphotoreceptor matrix. In: Progress in retinal research (Osborne N, Chader GJ, eds), pp 207-250. Oxford: Pergamon.

Hollyfield JG, Witkovsky P (1974) Pigmented retinal epithelium involvement in photoreceptor development and function. J Exp Zool 189:357-378.

Immel J, Steinberg RH (1986) Spatial buffering of $\mathrm{K}^{+}$by the retinal pigment epithelium. J Neurosci 6:3197-3204.

Israel P, Redfern N. Chader GJ (1978) Neural retinal-pigment epithelial interactions: morphological characteristics of cells grown together in culture. Ophthalmol Res 10:125-130.

Johnson AT, Kretzer FL, Hittner HM, Glazebrook PA, Bridges CD, Lam DM (1985) Development of the subretinal space in the preterm human eye: ultrastructural and immunocytochemical studies. J Comp Neurol 233:497-505.

Katz MI, Robison WG Jr (1984) Age-related changes in the retinal pigment epithelium of pigmented rats. Exp Eye Res 38:137-151.

Laemmli UK (1970) Cleavage of structural proteins during assembly of the head of bacteriophage T4. Nature 227:680-685.

Liu H, Gaur VP, Turner JE (1990) Photoreceptor cell survival and differentiation stimulated by rat retinal pigment epithelium in tissue culture. Invest Ophthalmol Vis Sci 31:75.

Liu L, Cheng SH, Jiang LZ, Hansmana T, Layer PG (1988) The pigment epithelium sustains cell growth and tissue differentiation of chicken retinal explants in vitro. Exp Eye Res 46:801-812.

Mansuy IM, van der Putten H, Schmid P, Meins M, Botter F, Monard D (1993) Variable and multiple expression of Protease Nexin-1 during mouse organogenesis and nervous system development. Development 119:1119-1134.

Marshall CJ (1993) Evolutionary relationships among the serpins. Philos Trans R Soc Lond [Biol] 342:101-119.

Meza I, lbarra G, Sabanero M, Martinez-Palomo A, Gerijido M (1980) Occluding junctions and cytoskeletal components in a cultured transporting epithelium. $\mathbf{J}$ Cell Biol 87:746 -754.

Miller S, Steinberg RH (1982) Potassium transport across the frog retinal pigment epithelium. J Membr Biol 67:199-209.

Mishima $H$, Hasebe $H$ (1978) Some observations in the fine structure of age changes of the mouse retinal pigment epithelium. Graefs Arch Klin Exp Ophthalmol 209:1-9.

Monard D (1988) Cell-derived proteases and protease inhibitors as regulators of neurite outgrowth. Trends Neurosci 11:541-544.
O'Farrell PH (1975) High resolution two-dimensional electrophoresis of proteins. J Biol Chem 250:4007-4021.

Pfeffer B (1990) Improved methodology for cell culture of human and monkey retinal pigment epithelium. In: Progress in retinal research (Osborne N, Chader GJ, eds), pp 251-291. Oxford: Pergamon.

Pignolo RJ, Cristofalo VJ, Rotenberg MO (1993) Senescent WI-38 cells fail to express EPC-1, a gene induced in young cells upon entry into the $\mathrm{G}_{0}$ state. $\mathrm{J}$ Biol Chem 268:8949-8957.

Porrello K, Bhat SP, Bok D (1991) Detection of interphotoreceptor retinoid-binding protein (IRBP) mRNA in human and cone-dominant squirrel retinas by in situ hybridization. $\mathbf{J}$ Histochem Cytochem 39171-176.

Rapaport DH, Herman KG, LaVail MM (1992) Epipolarization and incident light microscopy readily resolve an autoradiographic or heavy metal label from an obscuring background or second label. $J$ Neurosci Methods 41:231- 238.

Reinhard E, Suidan HS, Pavlik A, Monard D (1994) Glia-derived Nexin/Protease Nexin 1 is expressed by a subset of neurons in the rat brain. J Neurosci Res 37:256-270.

Remold-O'Donnell E (1993) The ovalbumin family of serpin proteins. FEBS Lett 315:105-108

Schweigerer L, Malerstein B, Neufeld G, Gospodarowicz D (1987) Basic fibroblast growth factor is synthesized in cultured retinal pigment epithelial cells. Biochem Biophys Res Commun 143:934-940.

Spoerri PE, Ulshafer RI, Iuldwig HG, Allen CB, Keely KC. (1988) Photoreceptor cell development in vitro: influence of pigment epithelium conditioned medium on outer segment differentiation. Eur J Cell Biol 46:362-367.

Steele FR, Chader GJ, Johnson LV, Tombran-Tink J (1993) Pigment epithelium-derived factor (PEDF): neurotrophic activity and identification as a unique member of the serine protease inhibitor (SERPIN) gene family. Proc Natl Acad Sci USA 90:1526-1530.

Steinberg RH, Wood I (1974) Pigment epithelial cell ensheathment of cone outer segments in the retina of the domestic cat. Proc R Soc Lond [Biol] 187:461-478.

Taniwaki T, Becerra SP, Chader GJ, Schwartz JP (1994) Pigment epithelium-derived factor (PEDF) is a survival factor for cerebellar granule cells in culture. $J$ Neurochem, in press.

Tombran-Tink J, Johnson LV (1989) Neuronal differentiation of retinoblastoma cells induce by medium conditioned by human RPE cells. Invest Ophthalmol Vis Sci 30:1700-1707.

Tombran-Tink J, Chader G.I, Iohnson I.V (1991) PF.DF: a pigment epithelium-derived factor with potent neuronal differentiative activity. Exp Eye Res 53:411-414.

Tombran-Tink J, Li A, Johnson MA, Johnson LV, Chader GJ (1992) Neurotrophic activity of interphotoreceptor matrix on human Y-79 retinoblastoma cells. J Comp Neurol 317:175-186.

Tombran-Tink J, Pawar H, Swaroop A, Rodriguez I, Chader GJ (1994) Localization of the gene for pigment epithelium-derived factor to chromosome $17 \mathrm{pl} 3.1$ and expression in cultured human retinoblastoma cells. Genomics 19:266-272.

Volmer G, Layer PG, Gierer A (1984) Reaggregation of embryonic chick retinal cells: pigment epithelial cells induced a high order of stratification. Neurosci Lett 48:191-196.

Waldbillig RJ, Pfeffer BA, Schoen TJ, Adler AA, Shen-Orr Z, Scavo L, LeRoith D, Chader GJ (1991) Evidence for an insulin-like growth factor autocrine-paracrine system in the retinal photoreceptor-pigment epithelial cell complex. J Neurochem 57:1522-1533.

Young RW, Bok D (1969) Participation of the retinal pigment epithelium in the rod outer segment renewal process. J Cell Biol 42:392403.

Ziellinger R, Swoboda H, Machacek E, Nekaham D, Sliutz G, Swoboda E, Kubista E (1992) Expression of catepsin D in head and neck cancer. Eur J Cancer 28A:1681-1691. 